\title{
Qatar Emerging as the Most Attractive FDI Destination in the GCC
}

\author{
Manuel Fernandez ${ }^{1} \&$ Robinson Joseph ${ }^{1}$ \\ ${ }^{1}$ Skyline University College, Sharjah, UAE \\ Correspondence: Manuel Fernandez, Skyline University College, PO Box 1797, University City of Sharjah, \\ Sharjah, UAE. Tel: 971-6544-1155. E-mail: qln_manuel@yahoo.com
}

Received: September 12, 2016

Accepted: September 27, 2016

Online Published: October 25, 2016

doi:10.5539/ijef.v8n11p175

URL: http://dx.doi.org/10.5539/ijef.v8n11p175

\begin{abstract}
In this era of globalization and high competition each and every nation is trying to attract maximum investments from overseas for the development and growth of the economy. All GCC economies are in the growth mode and are dependent on the revenue from oil, but the current decline in oil prices have very badly affected these economies and all are targeting to secure maximum foreign direct investments (FDI). Many of the developed nations and Multinational Corporations are in the search of the best destinations for their investments. The purpose of this study is to identify the most attractive destination for FDI in the GCC. The flow of FDI into a country depends on the availability of a number of factors. This study probes into the existence of each of these factors in the various GCC countries. Secondary data is used to rank each country on the basis of the parameters that attract FDI. The findings indicate that Qatar is emerging as the most attractive FDI destination in the GCC. This paper is useful for all countries and MNCs who are searching for investment destinations in the GCC as it ranks the countries on the basis of the attractiveness of various determinants of FDI.
\end{abstract}

Keywords: foreign direct investment, multinational corporations, gulf cooperation council, Qatar

\section{Introduction}

In this era of globalization, there is a great flow of investments between countries, investments flowing to destinations which are relatively more attractive than others. The investors whether it be individuals or corporates or nations will always prefer to invest in assets or projects which give attractive returns on investments, are relatively less risky and located in a stable and investor-friendly destinations. Every asset or corporate or country have different characteristics that attract different investors differently at different times. Many studies have been conducted to find out the various factors attracting the investments and have come out with results drawing attention to a number of factors.

Foreign Direct Investment (FDI) is defined as the investments made by a company in the investor country into a foreign host country. It can take the form of acquisition of already existing host firms or establishment of new companies in the host country or entering into a joint venture with an existing host firm. The prominence of FDI is growing globally because of the beneficial impact on both host country's economy and a firm's performance and profitability.

The inflow of FDI gives developing countries access to capital that would otherwise be not available, as Transnational Corporations (TNCs) often have privileged access to capital from the international banking sector. Similarly, FDI provides needed foreign exchange and therefore helps to adjust some of the macroeconomic imbalances in developing countries. All the countries in the GCC are in the growth mode but the resources available for development with each of them are limited and insufficient, hence each and every nation is competing to make the investment climate better and project itself as the most favored destination for the FDI.

The Gulf Cooperation Council (GCC) is an oil-based region with the largest proven crude oil reserves in the world (486.8 billion barrels), representing $35.7 \%$ of the world's total. The six countries of the GCC region, namely Bahrain, Kuwait, Oman, Qatar, Saudi Arabia and the United Arab Emirates, have enjoyed a spectacular economic boom until late 2008. The GCC economy tripled in size to $\$ 1.1$ trillion during 2002 to 2008 . For the GCC region, oil and gas sector represents approximately $73 \%$ of total export earnings and roughly $63 \%$ of government's revenues. The region is continuing its economic reform program, focusing on attracting domestic, regional and foreign private sector investments into various sectors like oil and gas, power generation, telecommunications, and real-estates. 
The State of Qatar is a narrow peninsula located in the center of the Persian Gulf between Bahrain, Saudi Arabia, and the United Arab Emirates. Since gaining independence in 1971, Qatar has quickly risen to prominence both regionally and internationally to become an economic, political and cultural powerhouse in the Middle East. Qatar accounts for one-third of global liquefied natural gas (LNG) trade and has emerged as an important global financial investor, labor importer, and donor. Qatar has the world's highest GDP per capita, averaging approximately $\$ 100,00$, and the lowest unemployment. Over the past five years Qatar has posted robust economic growth on the back of solid hydrocarbons revenues, State-led infrastructure development, and a rapidly maturing financial sector. According to Standard \& Poor's (S\&P), from 2010 to 2015 it was one of the fastest-growing economies in the world, posting average annual GDP growth of $8.6 \%$. Moreover, the population has grown rapidly due to the influx of foreign workers, increasing by an estimated $40 \%$ since 2010 (Oxford Business Group Country Report: Qatar 2016).

The basic objective of this study is to find out the most attractive FDI destination in the GCC and specifically to explore the attractiveness of Qatar as an emerging FDI destination in the GCC. The study proposes to rank all the GCC countries on various parameters that attract FDI and highlight the most attractive destination in the GCC so that anyone searching for investment destinations in the GCC can make use of the findings of this study to arrive at the most appropriate decisions.

This paper is organized as follows: Section 2 presents a literature review on FDI. Section 3 states the methodology. Section 4 focusses on analysis and discussions, and Section 5 concludes the paper.

\section{Literature Review}

Foreign direct investment is widely perceived as a powerful development engine for many receiving (host) countries. FDI can play a key part in enhancing the capacity of the host country to respond to the opportunities offered by global economic integration, an objective progressively perceived as one of the key aims of any development strategy. For all intents and purposes, all nations are actively seeking to attract FDI, because of its expected positive effect on income generation from capital inflows, advanced technology, management skills and market know-how (Cho, 2003).

Numerous studies have been conducted in different parts of the world and majority of the studies have tried to find out the various determinants of the FDI inflows and found that relevant determinants include the size and growth potential of the host market, economic stability, economic growth, geographic location, infrastructure, human capital, interest rate, degree of openness, per capita income, exchange rate, wage rate, quality of institutions, etc.

The presentation of the literature review is sequenced in such a manner that the literature relating to market size is presented first, followed by literature relating to the degree of openness, then exchange rate volatility, followed by political stability and then all literature relating to all other factors are arranged chronologically.

Market size is expected to have a positive relationship with FDI. Market-oriented FDI aims to set up enterprises to supply goods and services to the local market. The general implication is that host countries with larger market size, faster economic growth and a higher degree of economic development will provide more and better opportunities for these industries to exploit their ownership advantages and therefore, will attract more market-oriented FDI (OECD, 2000). The study by Resmini (2000), looking into manufacturing FDI, finds that countries in Central and Eastern Europe with larger populations tend to attract more FDI. The studies by Kravis and Lipesey (1982), and Na and Lightfoot (2006) revealed that FDI inflow has been largely attracted by the market size and market potential. Thus one may conclude that large host countries attract higher foreign direct investment due to larger potential demand.

Trade openness and foreign direct investments are interconnected according to Neumayer and Indra (2005). The authors show the importance of liberalizing economies with the objective of streamlining foreign direct investments. There is a sense of skepticism expressed by authors in relation to closed systems of trade considering the opportunities available as a result of trading overseas. Similarly, Resmini (2000), studying manufacturing investment in Central and Eastern Europe, found that increasing openness is beneficial for vertical FDI flows as in these sectors international trade flows in intermediate and capital goods are important.

The high volatility of the exchange rate of the currency in the host country discourages investment by the foreign firms as it increases uncertainty regarding the future economic and business prospects of the host country (Banga, 2003). The study by Campa (1993) examined how exchange rate uncertainty affected FDI and his study revealed that greater exchange rate uncertainty increased the option for firms to wait until investing in a market, depressing current FDI. Thus it can be said that TNCs prefer to do business with those countries with stable 
currency so that the home country profit is not widely affected by the exchange rate volatility.

Political stability and reliability determine the FDI inflows. TNCs prefer stable government so that their investment is protected. Political instability may be in the form of the negative attitude of the government towards TNCs, restrictions on fund transfer, currency convertibility, war, bureaucracy, and corruption. Political stability can also be measured by the number of changes of democratically elected governments (Gedam, 1996). The study by Root and Ahmed (1979), and Schneider and Frey (1985), looking at aggregate investment flows into developing economies found that political instability significantly affects FDI inflows.

Literature relating to all other determinants are presented chronologically. Dunning (1973) studied econometric models using a statistical analysis of surveys on the determinants of FDI and found that market force such as market size, growth and per capital income in the host country, and cost factors like labor cost and inflation as factors attracting FDI.

Tax policies including corporate and personal tax rates influence inward FDI. Other things being equal a country with lower tax rates should stand a greater chance of attracting FDI project than a country with higher rates (Chopra, 2003).

The study by Makki et al. (2004) on US food processing industry found that market size, per-capita income, and openness significantly affected US food processing firms' decisions to invest abroad.

According to Neumayer and Indra (2005), availability of raw materials provides investors with an added advantage with regards to producing efficiently.

The location is an important determinant of FDI inflows in the Gulf region and provides stakeholders with opportunities for growth as long as the right procedures are followed in terms of boosting growth (Mina, 2007). Empirically, Carr, Markusen and Maskus (2001) find that production by foreign affiliates of multinationals decreases with the distance between the host and source countries.

Casi and Resmini (2010) inspected the determinants of FDI in the EU region and found that the main determinants are GDP growth rate, labor costs, and market potential.

Khachoo and Khan (2012) conducted a study to examine the determinants of FDI in 32 developing countries from 1982 to 2008 using an econometric model. Their empirical results showed that market size, total reserve, and infrastructure were positively related to FDI inflows.

The study made by Uwubanmwen and Ajao (2012) shows that trade openness, interest rate, government size, and GDP exerted a positive control on cross-border investments in Nigeria and a negative relationship was found between FDI and exchange rates.

According to Milner (2013), the presence of a productive labor force is one of the determinants that influence the scope of FDI in a country.

The study by Melo and Quinn (2015) indicates that corruption has a negative impact on attracting Foreign Direct Investment.

Rauf et al. (2016) carried out a study in Pakistan for a period 1970 to 2013 and arrived at the conclusion that GDP, trade openness and political stability have a positive impact on the inflow of FDI, while terrorism has a negative effect on FDI inflows into Pakistan.

The following literature relates to the advantages of inflow of FDI. The foremost advantage of FDI is increased revenues that can be used for expanding growth opportunities in the investment destination. According to Almutawa et al. (2014), investments by foreigners refers to additional revenue that supports various economic projects of a country. According to Muysken and Samia (2006), unemployment rates are reduced as a result of capital injections and job opportunities from foreign-based companies. FDI also increases the competitive advantage of a country by developing financial and business hubs that boost economic growth. Mina (2007) points out that FDI promotes the economic growth of a nation by stimulating various sectors of the economy such as manufacturing and tourism. The study by Raphael et al. (2013) promotes the view that FDI increases investor confidence in a given economic bloc such as the Gulf by attracting new investment stakeholders in the long run.

In brief, the trend in FDI flows differs by region and country. Although FDI has innumerable effects on the economy of host countries and though most countries are trying hard to attract FDI, the inflow of FDI continues to be uneven, with some countries getting the lion's share and others barely getting any. These aspects have prompted this study to find out the most attractive FDI destination in the GCC. 


\section{Methodology}

The objective of this study is to find out the most attractive destination for FDI in the GCC and specifically to explore the attractiveness of Qatar as an emerging FDI destination in the GCC. This study is solely based on secondary data collected from local, regional and international agencies like Qatar Government, Qatar Central Bank, World Economic Forum, International Monetary Fund, Transparency International, World Bank group, United Nations and various publications of the statistical departments, governments, and the press. The study covers a period of five years from 2011-2012 to 2015-2016. The collected data are tabulated and analyzed using appropriate analytical tools.

\section{Analysis and Discussions}

Determinants

The Global Competitiveness Reports published every year by the World Economic Forum (WEF) assesses the competitiveness landscape of global economies, providing insight into the drivers of their productivity and prosperity. The Report series remains the most comprehensive assessment of national competitiveness worldwide. Table 1 gives the global competitiveness ranking for the GCC countries during the period 2011-2012 to 2015-2016 based on parameters like intensity of local competition, extent of market dominance, effectiveness of anti-monopoly policy, effect of taxation on incentives to invest, total tax rate as percentage of profits, number of procedures to start a business, number of days to start a business, agricultural policy costs, prevalence of trade barriers, trade tariffs as percentage duty, prevalence of foreign ownership, business impact of rules on FDI, burden of customs procedures, imports as a percentage of GDP, degree of customer orientation and buyer sophistication. Table 2 gives the filtered ranking for GCC economies.

Table 1. The competitiveness of the GCC economies: Global ranking during 2011-2012 to 2015-2016

\begin{tabular}{lccccc}
\hline Country & \multicolumn{5}{c}{ Global Rank } \\
\hline & $2011-2012$ & $2012-2013$ & $2013-2014$ & $2014-2015$ & $2015-2016$ \\
\cline { 2 - 6 } Qatar & 14 & 11 & 13 & 16 & 14 \\
United Arab Emirates & 27 & 24 & 19 & 12 & 17 \\
Saudi Arabia & 17 & 18 & 20 & 24 & 25 \\
Kuwait & 34 & 37 & 36 & 40 & 34 \\
Bahrain & 37 & 35 & 43 & 44 & 39 \\
Oman & 32 & 32 & 33 & 46 & 62 \\
Number of Economies ranked & 142 & 144 & 148 & 144 & 140 \\
\hline
\end{tabular}

Source: The Global Competitiveness Reports 2011-2012 to 2015-2016.

Table 2. The competitiveness of the GCC economies: Filtered ranking during 2011-2012 to 2015-2016

\begin{tabular}{lccccc}
\hline Country & \multicolumn{5}{c}{ Filtered Rank } \\
\cline { 2 - 6 } & $2011-2012$ & $2012-2013$ & $2013-2014$ & $2014-2015$ & $2015-2016$ \\
\hline Qatar & 1 & 1 & 1 & 2 & 1 \\
UAE & 3 & 3 & 2 & 3 & 2 \\
Saudi Arabia & 2 & 2 & 3 & 4 & 3 \\
Kuwait & 5 & 6 & 6 & 5 & 4 \\
Bahrain & 6 & 5 & 4 & 6 & 5 \\
Oman & 4 & 4 & 5 & 6 \\
\hline
\end{tabular}

Source: compiled from the Global Competitiveness Reports 2011-2012 to 2015-2016.

The Global Competitiveness Reports for the period 2011-2012 to 2015-2016 rank Qatar as the most competitive nation among the GCC nations for all years except 2014-2015 when the UAE is ranked first, but during the current year, 2015-2016, Qatar has regained the top position among the GCC nations and $14^{\text {th }}$ rank globally by moving up two positions from the previous year. It may be noted that Qatar is ranked ahead of most EU countries, including the UK, France, Italy and Spain, and also doing better than Japan, South Korea, China, and India. It will be unfair not to mention the special comments made by the WEF. The WEF has cited numerous strengths, including the ease of accessing capital, internet connectivity, a high level of physical security, access to finance and a highly efficient goods and services market, to mention a few. The report noted that the Qatari 
government had played an important role in promoting and fostering innovation, with Qatar ranking first in the world for government procurement of advanced technology products. An analysis is made into various determinants of FDI beginning with market size.

\subsection{Market Size, Growth and Efficiency}

Market size, growth in market size and market efficiency are important determinants of FDI. The market size and the growth prospects of the market of the host country are important pull factors and are positively related to the level of FDI flows (Dunning, 1993 and Chandalert, 2000). A huge market size allows the attainment of economies of scale, and transaction costs are lower in countries with higher levels of economic development (Caves, 1971; Zhao \& Zhu, 2000).

Qatar enjoys one of the highest GDP per capita rankings in the world, averaging approximately US\$100,000 per person. The population of Qatar is rapidly increasing, due to this rapid increase the Ministry of Development Planning and Statistics (MDPS), at the recommendation of the UN, conducted a mini-census in 2015. Results show that the total population increased by $40 \%$ since the 2010 census was conducted. Results from 2015 indicate the population was 2.4 million, up from 1.7 million recorded five years prior. This equates to a $7.2 \%$ annual average increase in the total population. This high population growth is mainly because of the massive inflows of socially and culturally diverse expatriate workers needed to support the country's infrastructure developments, particularly in relation to hosting the FIFA 2022 World Cup.

But the current rate of population growth is even higher, the population of Qatar, including both nationals and foreigners, was approximately 2.52 million at the end of March 2016, and the total population in March 2015 was approximately 2.34 million, a $7.8 \%$ increase year-on-year according to figures from MDPS. The Qatar domestic market has grown over the years, a larger population means a better and larger domestic market that can consume more goods and services provided by investors.

The market size can be measured by the growth of the population of the country, but Qatar deserves a different treatment as it is one of the favored tourist destinations in the GCC and since it is a tax-free country tourist prefer to do a lot of shopping as the prices are relatively lower because of the tax advantage. Hence in this study the market size or the population is considered to include the citizens of the country, the residents, and tourists.

Backed by a coordinated government strategy and strong investments in key economic enablers such as infrastructure, Qatar's tourism industry continues to grow at a steady pace. Since 2010 Qatar has seen arrival numbers rise over $72 \%$ to reach 2.93 million in 2015. Foreign arrivals rose at an average of $11.5 \%$ a year in 2010-15, according to the government agency responsible for planning, regulating and promoting the sector, Qatar Tourism Authority (QTA). Qatar plans to attract 5 million visitors over the next three years, and between 6.7 million and 7.4 million annual visitors by 2030, according to a Doha News report. (Gulf News, 2016).

The initiatives of the government and other stakeholders in the Qatar have boosted the arrival of tourists and the performance of the tourism industry in the recent past and it is expected to grow at an exponential rate in the near future as Qatar would be hosting the 2022 FIFA World Cup. Thus the growing population, of the residents and the tourists, brings plenty of opportunities for the investors both domestic and international. This definitely will attract more FDI. Table 3 gives the global ranking and Table 4 gives the filtered ranking for market efficiency during the period 2011-12 to 2015-16.

Table 3. Goods market efficiency economies: Global ranking during 2011-2012 to 2015-2016

\begin{tabular}{|c|c|c|c|c|c|}
\hline \multirow[t]{2}{*}{ Economies } & \multicolumn{5}{|c|}{ Global Rank } \\
\hline & 2011-2012 & 2012-2013 & 2013-2014 & 2014-2015 & 2015-2016 \\
\hline UAE & 10 & 5 & 4 & 3 & 3 \\
\hline Qatar & 17 & 10 & 3 & 4 & 5 \\
\hline Bahrain & 6 & 16 & 19 & 21 & 18 \\
\hline Saudi Arabia & 4 & 14 & 27 & 35 & 29 \\
\hline Oman & 23 & 25 & 18 & 28 & 52 \\
\hline Kuwait & 53 & 90 & 90 & 106 & 98 \\
\hline
\end{tabular}

Source: The Global Competitiveness Reports 2011-2012 to 2015-2016. 
Table 4. Goods market efficiency economies: Filtered ranking 2011-2012 to 2015-2016

\begin{tabular}{lccccc}
\hline Economies & \multicolumn{5}{c}{ Filtered Rank } \\
\cline { 2 - 6 } & $2011-2012$ & $2012-2013$ & $2013-2014$ & $2014-2015$ & $2015-2016$ \\
\hline UAE & 3 & 1 & 2 & 1 & 1 \\
Qatar & 4 & 2 & 1 & 2 & 2 \\
Bahrain & 2 & 4 & 4 & 3 & 3 \\
Saudi Arabia & 1 & 3 & 5 & 5 & 4 \\
Oman & 5 & 5 & 3 & 4 & 5 \\
Kuwait & 6 & 6 & 6 & 6 & 6 \\
\hline
\end{tabular}

Source: compiled from the Global Competitiveness Reports 2011-2012 to 2015-2016.

During the five-year period of study, the UAE is in the top rank for three years, it was in the third position in 2011-12 from where it improved and is currently at the top of the table. Whereas, Qatar was ranked four in 2011-12 and from there it had been continuously improving and in 2013-14 it reached the top of the table but after that it lost the top slot to the UAE and is currently ranked second among the GCC nations and globally it has the fifth best position as far as market efficiency for goods is concerned. This continuous improvement is quite appreciable and certainly is an attraction for the FDI, and at this rate, Qatar would be the most attractive destination for FDI in the GCC in the near future.

\subsection{Infrastructure}

Infrastructure is a major determinant of FDI. Excellent infrastructure plays a major role in the profitability of Multinational Corporations (MNCs), and thus, their decision about FDI location. Table 5 gives the global ranking for the best infrastructure in the world, and Table 6 gives the filtered ranking for the GCC, during the period 2011-12 to 2015-16 based on quality of roads, quality of railroad infrastructure, quality of port infrastructure, quality of air transport infrastructure, available airline seat for comfortable travel to different parts of the world, quality of electricity supply, mobile telephone subscriptions, fixed telephone lines, etc.

Table 5. Infrastructure: Global ranking during 2011-2012 to 2015-2016

\begin{tabular}{lccccc}
\hline Economies & \multicolumn{5}{c}{ Global Rank } \\
\cline { 2 - 6 } & $2011-12$ & $2012-13$ & $2013-14$ & $2014-15$ & $2015-16$ \\
\hline UAE & 8 & 8 & 5 & 3 & 4 \\
Qatar & 27 & 31 & 28 & 24 & 18 \\
Bahrain & 30 & 29 & 30 & 31 & 29 \\
Saudi Arabia & 25 & 26 & 31 & 30 & 30 \\
Oman & 28 & 33 & 32 & 33 & 36 \\
Kuwait & 50 & 52 & 53 & 61 & 54 \\
\hline
\end{tabular}

Source: The Global Competitiveness Reports 2011-2012 to 2015-2016.

Table 6. Infrastructure: Filtered ranking for GCC during 2011-2012 to 2015-2016

\begin{tabular}{lccccc}
\hline Economies & \multicolumn{5}{c}{ Filtered Rank } \\
\cline { 2 - 6 } & $2011-12$ & $2012-13$ & $2013-14$ & $2014-15$ & $2015-16$ \\
\hline UAE & 1 & 1 & 1 & 1 & 1 \\
Qatar & 3 & 4 & 2 & 2 & 2 \\
Bahrain & 5 & 3 & 3 & 4 & 3 \\
Saudi Arabia & 2 & 2 & 5 & 3 & 4 \\
Oman & 4 & 5 & 6 & 6 & 5 \\
Kuwait & 6 & 6 & 4 & 6 \\
\hline
\end{tabular}

Source: compiled from the Global Competitiveness Reports 2011-2012 to 2015-2016.

The UAE tops the table during the period of study. Qatar was globally ranked 27 and 31 respectively during 2011-12 and 2012-13. But the Government of Qatar has been continuously investing in infrastructure development projects so as to have the best infrastructure in the world, this has started showing results and currently, it is ranked the eighteenth best in the world, a tremendous improvement from the $31^{\text {st }}$ rank in 2012-13. 
The award of the right to host 2022 FIFA World Cup to Qatar, has further fueled its infrastructural development dreams and Qatar has brought out long-term development plans in preparation for hosting the FIFA World Cup proposing to spend up to US $\$ 150$ billion on infrastructure projects over the next 5-6 years. These major projects include the New Doha International Airport, New Doha Port, Qatar Railways Project, Lusail, and the Qatar-Bahrain Causeway. Most important thing to note is that the improvement is continuous and at this rate, it may reach the top ten ranks in a year or two. Further, a scanning of the Logistics Performance Index is done to understand the position of Qatar.

\subsubsection{Logistics Performance Index}

The Logistics Performance Index (LPI) is an indicator of logistics sector performance, combining qualitative and quantitative data on six core performance components, namely: (1) The efficiency of customs and border clearance, (2) The quality of trade and transport infrastructure, (3) The ease of arranging competitively priced shipments, (4) The competence and quality of logistics services, (5) The ability to track and trace consignments, (6) The frequency with which shipments reach consignees within scheduled or expected delivery times. Table 7 gives the ranking for the GCC economies in 2016.

Table 7. Logistics performance index: GCC economies in 2016

\begin{tabular}{lcc}
\hline Country & LPI Global Rank* & Filtered Rank \\
\hline United Arab Emirates & 13 & 1 \\
Qatar & 30 & 2 \\
Bahrain & 44 & 3 \\
Oman & 48 & 4 \\
Saudi Arabia & 52 & 5 \\
Kuwait & 53 & 6 \\
\hline
\end{tabular}

Source: Logistics Performance Index, 2016, the World Bank.

*2016 rank out of 160 economies.

In the Logistics Performance Index Qatar is ranked second best among the GCC countries and $30^{\text {th }}$ globally among 160 countries based on six different parameters. The parameter-wise detailed ranking is given in Table 8 .

Table 8. Logistics performance index: Parameter-wise ranking of GCC economies in 2016

\begin{tabular}{|c|c|c|c|c|c|c|}
\hline \multirow[t]{2}{*}{ Country } & \multicolumn{6}{|c|}{ Global Rank* } \\
\hline & Customs & Infrastructure & International shipments & Logistics competence & Tracking \& tracing & Timeliness \\
\hline UAE & 12 & 13 & 7 & 18 & 18 & 18 \\
\hline Qatar & 21 & 28 & 26 & 29 & 35 & 35 \\
\hline Bahrain & 41 & 48 & 41 & 33 & 44 & 51 \\
\hline Oman & 61 & 34 & 40 & 38 & 57 & 57 \\
\hline Saudi Arabia & 68 & 40 & 48 & 54 & 49 & 53 \\
\hline Kuwait & 56 & 56 & 24 & 70 & 53 & 55 \\
\hline
\end{tabular}

Source: Logistics Performance Index, 2016, the World Bank.

*2016 rank out of 160 economies.

\subsection{Stable Currency}

The flow of FDI is influenced by the volatility of the exchange rates. Currency depreciation may make a country's assets undervalued, thereby encouraging FDI but at the same time, a depreciating currency may also signal future depreciation of that currency to investors, thereby negatively influencing FDI. Investors prefer a stable and less volatile currency which ensures that their profitability is least affected by the vagaries of exchange rate fluctuations and they need not spend their time and money in managing the forex risk.

The currency of Qatar is pegged to the US dollar. Thus the investors are assured an exchange rate of US\$ $=3.64$ Qatari riyal. This pegged exchange rate will continue to act as an important attraction for inflow of FDI into this country.

\subsection{Openness of the Economy}

The size, growth and other characteristics of the domestic market play an important role in attracting FDI, but 
domestic market factors are predictably less relevant in export-oriented firms. Many studies have suggested the importance of an open economy in attracting FDI in export-oriented sectors (ODI, 1997; Erdal \& Tatoglu, 2002; Singh \& Jun, 1995). In an open economy, it is easier to import raw materials and capital goods which are necessary for domestic and foreign investment. Singh and Jun (1995) found that export, particularly manufacturing exports, are significant determinants of FDI flows. Thus friendly import-export policies significantly influence the flow of FDI.

Qatar is aspiring to be a leading financial and business hub in the region and in pursuit of achieving this status it has recently undertaken a number of structural reforms intended to enhance the entrepreneurial and investment regimes and to enhance the country's openness to global commerce and investments.

Qatar's international relations is focused on maintaining good relations with neighbouring countries, the formation of strategic alliances with major powers, both international and regional, and branding the country as the most peaceful and stable in the region. It encourages settlement of international disputes by peaceful means and supporting the rights of people to self-determination. Qatar has been largely unaffected by social unrest and civil conflicts that have fragmented some other countries in the region and has relatively high level of political stability and respect for the rule of law and this is being reinforced by the ranking of 2016 Index of Economic Freedom.

According to the 2016 Index of Economic Freedom, published by the Wall Street Journal and the Heritage Foundation, the Middle East has become more economically free last year. This Index was launched in 1995 and it evaluates countries in four broad policy areas that affect economic freedom: rule of law; limited government; regulatory efficiency; and open markets. There are 10 specific categories: property rights, freedom from corruption, fiscal freedom, government spending, business freedom, labor freedom, monetary freedom, trade freedom, investment freedom, and financial freedom. Scores in these categories are averaged to create an overall score. Table 9 gives the ranking of the GCC economies during 2016.

Table 9. Ranking of GCC economies: Index of economic freedom 2016

\begin{tabular}{lccc}
\hline Economies & Global Rank & Overall Score & Filtered Ranking \\
\hline Bahrain & 18 & 74.3 & 1 \\
United Arab Emirates & 25 & 72.6 & 2 \\
Qatar & 34 & 70.7 & 3 \\
Oman & 52 & 67.1 & 4 \\
Kuwait & 74 & 62.7 & 5 \\
Saudi Arabia & 78 & 62.1 & 6 \\
\hline
\end{tabular}

Source: Index of Economic Freedom, 2016 by Wall Street Journal \& Heritage Foundation.

The index has categorized Bahrain, the United Arab Emirates, and Qatar as 'mostly free,' and Oman, Kuwait, and Saudi Arabia as 'moderately free' economies. The world average score is 60.7 and GCC nations are having scores above this, showing the transparent and favorable business climate and a high degree of political stability prevailing in the GCC.

\subsection{Political Risk}

TNCs usually assess political risk before investing in a certain country. There are many forms of political risks, but the extreme form is the possibility that the host country will take over a subsidiary. However, this form of political risk is an extreme case and not very common in today's global world. The more common forms of political risk include the negative attitude of the host government to TNCs, blockage of fund transfer, currency inconvertibility, war, bureaucracy, and corruption.

Qatar is ruled by the Al Thani family since the mid-19th century. Qatar is a hereditary constitutional monarchy which tolerates no political opposition and the head of State is Emir, whose family holds a monopoly on political power. The Emir appoints the prime minister and cabinet and also appoints an heir apparent after consulting with the ruling family and other notables. The constitution stipulates the formation of an elected parliament, the Advisory Council (Majlis Al-Shura). Elections are to be held for 30 of the 45 seats for 4-year terms, while the Emir has the power to appoint the other 15 members. Till date no elections have taken place, the members of the existing 35-member Council were all appointed by the Emir. Furthermore, the Emir recently renewed the council's mandate for another three years, effectively postponing legislative elections until at least 2019. 
Central Municipal Council members, who are elected to serve four-year terms, enjoy limited powers. Municipal elections in Qatar were held for the fifth time on 13 May 2015. Only a small percentage of the country's population is permitted to vote or hold office. The government does not permit the existence of political parties. Till date there had been no major political unrest in the country and one does not expect things to go wrong in the near future because of the strong political will and farsightedness of its rulers in formulating strategies for the growth of the country and prosperity of all citizens and residents. Political unrest springs up only when there is discontent among the citizens of the country and as far as Qatari nations are concerned most of them are content and happy with plenty of opportunities to fulfill their dreams provided they can put effort to convert their dreams into realities. Hence the international investors can be sure that they will get a warm welcome in Qatar, their funds will not be blocked, enjoy easy convertibility, least bureaucracy bottlenecks, and low corruptions.

\subsection{Bribery and Corruption}

Corruption distorts competition and investment and hinders free and fair trade. The study by Mauro (1995) found that corruption lowers investment and thereby economic growth. The study by Tanzi and Davoodi (1997) shows that corruption increases public investment while reducing its productivity. In regard to foreign direct investment, studies have shown that there exist economic consequences of corruption, such as its effect on the composition of FDI. The study by Smarzynska and Wei (2001) exposed that the extent of corruption in the host country greatly influences the choice of entry mode for international investors. Corruption makes dealing with government officials less transparent and costlier, particularly for foreign investors. To circumvent these, local partners are very often opted in, having a local partner to lower the transaction cost, such as the cost of securing local permits, etc. At the same time sharing ownership may lead to technology leakage. Both costs of local permits and losses from technology leakage are positively related to the extent of corruption in a host country.

When corruption level is sufficiently high no investment will take place. Corruption in Qatar is relatively low and is among the lowest in the Middle East and North African region. The use of influential middlemen and giving of a gift, known as 'wasta', play a major role in the business culture of Qatar, especially in the public sector. On 30 January 2007, Qatar ratified the United Nations (UN) Convention against Corruption. The Official Corruption and Government Transparency law provides criminal penalties for official corruption. Under the Qatar Penal Code, it is an offense for the Public Official who accepts a 'bribe' in return for committing an act or omitting to act, other than where this is part of their function as a public servant, and for the person who pays or offers that 'bribe'. However, foreign companies must rely on local sponsorship if they want to succeed, and ruling families' involvement in the economy creates an uneven playing field.

Transparency International (TI) has published the Corruption Perceptions Index (CPI) since 1995, annually ranking countries by their perceived levels of corruption, as determined by expert assessments and opinion surveys. The CPI generally defines corruption as "the misuse of public power for private benefit." Table 10 displays the ranks assigned to the GCC countries during the last five years.

Table 10. Corruption ranking for the GCC, 2011 to 2015

\begin{tabular}{lccccc}
\hline Economies & \multicolumn{5}{c}{ Global Rank } \\
\cline { 2 - 6 } & 2011 & 2012 & 2013 & 2014 & $2015^{*}$ \\
\hline Qatar & 22 & 27 & 28 & 26 & 22 \\
United Arab Emirates & 28 & 27 & 26 & 25 & 23 \\
Saudi Arabia & 57 & 66 & 63 & 55 & 48 \\
Bahrain & 46 & 53 & 57 & 55 & 50 \\
Kuwait & 54 & 66 & 69 & 67 & 55 \\
Oman & 50 & 61 & 61 & 64 & 60 \\
\hline
\end{tabular}

Source: The Corruption Perceptions Index 2011 to 2015 by Transparency International.

*2015 rank out of 168 countries.

The ranking by the Corruption Perceptions Index reinforces that Qatar and the UAE have the lowest level of corruption in the GCC and both are improving year by year in reducing corruption.

\subsection{Productive and Diversified Labor Force}

A vibrant labor force in Qatar is attracting foreign direct investments. When international investors look for an investment destination, considerations about the skilled nature of the labor force are a matter of priority that determines their scope of success in a country (Brakman et al., 2008). Qatar has made strides in terms of 
developing and attracting a labor force that can handle all forms of tasks and also align their knowledge with international trends.

Qatar places major emphasis on education in line with the 'Qatar National Vision for 2030' (QNV 2030), which aims to make the country a self-sufficient, sustainable economy with a highly developed human capital. One of the pillars of 'the Vision' is Human Development, which it aims to achieve through increased education opportunities for its people. To meet this goal, Qatar has established a number of educational institutions both at the school as well as post-secondary level, which will, in turn, augment the country's labour force. It will prepare individuals for a changing world in which they will require highly complex technical skillset.

The country had been bringing in all possible improvements in tandem with international best practices so as to provide the best work environment that attracts professionals from all walks of life and both skilled and unskilled workforces from all parts of the world. Foreigners make up approximately $90 \%$ of the country's total population. The population is highly heterogeneous - multiethnic, multicultural, multilingual and multi-skilled. Of recent the labor laws have become more friendly and liberal and hope it will continue to become better in the future. Table 11 gives the global ranking for the best labor market efficiency in the world, and Table 12 gives the filtered ranking for the GCC, during the period 2011-2012 to 2015-2016 based on cooperation in labor-employer relations, flexibility of wage determination, hiring and firing practices, redundancy costs, effect of taxation on incentives to work, pay and productivity, reliance on professional management, country capacity to retain talent, country capacity to attract talent, and the ratio of women in labor force.

Table 11. Labor market efficient: Global ranking during 2011-2012 to 2015-2016

\begin{tabular}{lccccc}
\hline Economies & \multicolumn{5}{c}{ Global Rank } \\
\cline { 2 - 6 } & $2011-12$ & $2012-13$ & $2013-14$ & $2014-15$ & $2015-16$ \\
\hline UAE & 28 & 7 & 9 & 8 & 11 \\
Qatar & 22 & 14 & 6 & 10 & 14 \\
Bahrain & 19 & 21 & 19 & 26 & 24 \\
Saudi Arabia & 50 & 59 & 70 & 64 & 60 \\
Oman & 40 & 36 & 105 & 48 & 89 \\
Kuwait & 62 & 98 & & 116 & 117 \\
\hline
\end{tabular}

Source: The Global Competitiveness Reports 2011-2012 to 2015-2016.

Table 12. Labor market efficient: Filtered ranking for GCC during 2011-2012 to 2015-2016

\begin{tabular}{lccccc}
\hline Economies & \multicolumn{5}{c}{ Filtered Rank } \\
\cline { 2 - 5 } & $2011-12$ & $2012-13$ & $2013-14$ & $2014-15$ & $2015-16$ \\
\hline UAE & 3 & 1 & 2 & 1 & 1 \\
Qatar & 2 & 2 & 1 & 2 & 2 \\
Bahrain & 1 & 3 & 3 & 3 & 3 \\
Saudi Arabia & 5 & 5 & 5 & 4 & 5 \\
Oman & 4 & 4 & 6 & 6 & 6 \\
Kuwait & 6 & 6 & 6 & & 5 \\
\hline
\end{tabular}

Source: compiled from the Global Competitiveness Reports 2011-2012 to 2015-2016.

Currently, the UAE ranks first and Qatar ranks second among the GCC economies on the basis of labor market efficiency. Globally the UAE is the eleventh and Qatar is fourteenth best. An efficient labor market, easy availability of skilled labor, the ready availability of training facility and capacity to attract and retain right talent from other parts of the globe are the most important factors that attract international investors to Qatar.

\subsection{Availability / Easiness to Import of Raw Materials}

Availability of raw materials means that international investors can do business in the country without having concerns for the supply of production materials. In Qatar, there is a range of raw materials that can be used for manufacturing processes and has motivated many investors abroad to invest in the country. The country is endowed with natural resources such as oil and minerals that are vital to the manufacturing sector and these materials are available cheaply as compared to other regions where the cost of materials is high. Qatar offers customs exemption on industrial project on its imports of raw materials or half-manufactured goods necessary 
for production and not available in the local market. The Government of the country has been giving special attention to ensure the availability of raw materials in the country knowing that this will boost the economy in the long run.

\subsection{Geographical Location}

Location advantage is another factor that determines the accessibility by manufacturers and provides them with cost benefits as compared to regions where there is no location advantage for raw materials. Strategic locational of Qatar provides investors with opportunities to maximize production and trade efficiencies through the application of cost reduction methods.

\subsection{Technological Readiness and Innovation}

Technology is an important consideration made by foreign investors because it determines the scope of operational efficiency. Qatar government has allocated resources for boosting technology just like in other developed market economies. From an investment perspective, the lack of efficient technology systems implies that operations would be slow and costly, and, thus, there will be a need for choosing destinations with a higher level of technology. Partnerships and investment conferences conducted by the Qatar government to market the country have shown time and again that technology is prevalent in the country and that foreign investors should not be worried about technological readiness and efficiency issues. Table 13 gives the global ranking for the technological readiness countries, and Table 14 gives the filtered ranking for the GCC nations, during the period 2011-12 to 2015-16 based on availability of latest technologies, firm-level technology absorption, FDI and technology transfer, individuals using the internet, fixed broadband internet subscriptions, international internet bandwidth and mobile broadband subscriptions.

Table 13. Technologically ready economies: Global ranking during 2011-2012 to 2015-2016

\begin{tabular}{lccccc}
\hline Economies & \multicolumn{5}{c}{ Global Rank } \\
\cline { 2 - 5 } & $2011-12$ & $2012-13$ & $2013-14$ & $2014-15$ & $2015-16$ \\
\hline UAE & 30 & 32 & 28 & 24 & 30 \\
Qatar & 33 & 27 & 31 & 31 & 31 \\
Bahrain & 39 & 39 & 32 & 34 & 34 \\
Saudi Arabia & 43 & 35 & 41 & 45 & 42 \\
Kuwait & 65 & 74 & 69 & 54 & 56 \\
Oman & 51 & 54 & 56 & 57 & 62 \\
\hline
\end{tabular}

Source: Global Competitiveness Reports 2011-2012 to 2015-2016.

Table 14. Technologically ready economies: Filtered ranking for GCC during 2011-2012 to 2015-2016

\begin{tabular}{lccccc}
\hline Economies & \multicolumn{5}{c}{ Filtered Rank } \\
\cline { 2 - 5 } & $2011-12$ & $2012-13$ & $2013-14$ & $2014-15$ & $2015-16$ \\
\hline UAE & 1 & 2 & 1 & 1 & 2 \\
Qatar & 2 & 1 & 2 & 2 & 3 \\
Bahrain & 3 & 4 & 3 & 3 & 4 \\
Saudi Arabia & 4 & 3 & 4 & 6 & 5 \\
Kuwait & 6 & 6 & 6 & 5 & 6 \\
Oman & 5 & 5 & 5 & & 2 \\
\hline
\end{tabular}

Source: compiled from the Global Competitiveness Reports 2011-2012 to 2015-2016.

Qatar is the second the best in the GCC as far as technological readiness is concerned. Now let us look into how the country facilitates and promotes innovations. With the Government support and encouragement, the country is giving much importance to innovations and enhancement of knowledge. According to the 2015-2016 Global Competitiveness Report, the Qatar government had played an important role in promoting and fostering innovations and ranks first in the world for government procurement of advanced technology products. Table 15 gives the global ranking and Table 16 gives the filtered ranking for innovation affable countries in the GCC during 2011-12 to 2015-16 based on capacity for innovation, quality of scientific research institutions, company spending on $\mathrm{R} \& \mathrm{D}$, university-industry collaboration in $\mathrm{R} \& \mathrm{D}$, Government procurement of advanced tech products, availability of scientists and engineers, and PCT (patent cooperation treaty) applications made for 
patents.

Table 15. Innovation friendly economies: Global ranking during 2011-2012 to 2015-2016

\begin{tabular}{lccccc}
\hline Economies & \multicolumn{5}{c}{ Global Rank } \\
\cline { 2 - 6 } & $2011-12$ & $2012-13$ & $2013-14$ & $2014-15$ & $2015-16$ \\
\hline Qatar & 18 & 19 & 16 & 14 & 14 \\
UAE & 28 & 28 & 28 & 24 & 26 \\
Saudi Arabia & 26 & 29 & 30 & 33 & 34 \\
Bahrain & 61 & 72 & 73 & 60 & 56 \\
Oman & 47 & 47 & 45 & 64 & 103 \\
Kuwait & 84 & 108 & 118 & 111 & 109 \\
\hline
\end{tabular}

Source: compiled from the Global Competitiveness Reports 2011-2012 to 2015-2016.

Table 16. Innovation friendly economies: Filtered ranking for GCC during 2011-2012 to 2015-2016

\begin{tabular}{|c|c|c|c|c|c|}
\hline \multirow[t]{2}{*}{ Economies } & \multicolumn{5}{|c|}{ Filtered rank } \\
\hline & 2011-12 & $2012-13$ & 2013-14 & 2014-15 & $2015-16$ \\
\hline Qatar & 1 & 1 & 1 & 1 & 1 \\
\hline UAE & 3 & 2 & 2 & 2 & 2 \\
\hline Saudi Arabia & 2 & 3 & 3 & 3 & 3 \\
\hline Bahrain & 5 & 5 & 5 & 4 & 4 \\
\hline Oman & 4 & 4 & 4 & 5 & 5 \\
\hline Kuwait & 6 & 6 & 6 & 6 & 6 \\
\hline
\end{tabular}

Source: compiled from the Global Competitiveness Reports 2011-2012 to 2015-2016.

Qatar ranks the best in the GCC for innovations during the period of study, this definitely will act as a pull factor that attracts modern business ventures to this country.

\subsection{Developed Financial Market}

Table 17 gives the global ranking and Table 18 gives the filtered ranking for the countries with well-developed financial markets in the GCC during 2011-2012 to 2015-2016 based on availability of financial services, affordability of financial services, financing through local equity market, ease of access to loans, venture capital availability, soundness of banks, regulation of securities exchanges and legal rights.

Table 17. Financially developed markets: Global ranking during 2011-2012 to 2015-2016

\begin{tabular}{lccccc}
\hline Economies & \multicolumn{4}{c}{ Global Rank } \\
\cline { 2 - 5 } & $2011-12$ & $2012-13$ & $2013-14$ & $2014-15$ & 13 \\
Qatar & 19 & 14 & 13 & 17 & 13 \\
UAE & 33 & 25 & 24 & 2516 & 31 \\
Bahrain & 14 & 18 & 27 & 30 & 28 \\
Saudi Arabia & 16 & 22 & 21 & 41 \\
Oman & 30 & 26 & 70 & 75 \\
Kuwait & 59 & 76 & 73 & 77 \\
\hline
\end{tabular}

Source: compiled from the Global Competitiveness Reports 2011-2012 to 2015-2016.

Table 18. Financially developed markets: Filtered ranking for GCC during 2011-2012 to 2015-2016

\begin{tabular}{lccccc}
\hline Economies & \multicolumn{4}{c}{ Filtered Rank } \\
\cline { 2 - 5 } & $2011-12$ & $2012-13$ & $2013-14$ & $2014-15$ \\
\hline Qatar & 3 & 1 & 1 & 1 & $2015-16$ \\
UAE & 5 & 4 & 3 & 2 & 5 \\
Bahrain & 1 & 2 & 4 & 4 & 3 \\
Saudi Arabia & 2 & 3 & 5 & 3 & 5 \\
Oman & 4 & 5 & 2 & 6 \\
Kuwait & 6 & 6 & 6 & 6 \\
\hline
\end{tabular}

Source: compiled from the Global Competitiveness Reports 2011-2012 to 2015-2016. 
Qatar tops the list in the GCC for financial market development and globally is the $13^{\text {th }}$ best. Qatar's capital markets and more specifically the Qatar Stock Exchange (QSE) have all recently enjoyed a number of upgrades. Morgan Stanley Capital International (MSCI) upgraded QSE from frontier market status to emerging market status in May of 2014. S\&P followed suit, upgrading Qatar in September 2014. In September 2015 the Qatar Stock Exchange was upgraded to "secondary emerging market" status by the global index firm FTSE Russell. The move by MSCI is a major sign of approval from institutional investors for the country's stock market and is expected to attract more stable sources of capital to local equities. Qatar is also ranked as the $35^{\text {th }}$ most important financial center in the world, as per the Global Financial Centers Index (2016).

\subsection{Low Tax Rates \& Clarity of Taxation Policies}

\subsubsection{Income Tax}

The individual incomes are not taxed. This attracts plenty of high income earning professionals and skilled workers to this country. This also reduces the cost of running a business in Qatar because at the time of salary negotiations the prospective employee looks at the after-tax annual pay package offered. The country proposes to continue this status with the intent to attract highly talented and skilled workforce needed for the domestic and MNCs operating in the country.

\subsubsection{Corporate Tax}

The country charges a flat $10 \%$ corporate income tax on businesses other than those wholly owned by GCC nationals. However, where special agreements have been concluded between the Qatar government and foreign companies in the oil and gas industry and for the development of natural wealth and resources, the tax rates specified in the agreements will continue to apply. If the agreement does not specify a tax rate, then a tax rate of $35 \%$ is expected to apply in those sectors. These corporate tax rates had been consistent from 2010 to 2016, the rationale of this policy is to ensure that the cost of doing business is fair and justified in relation to revenues earned by foreign companies.

\subsection{Lower Interest Rates}

High interest rates tend to slow the growth of an economy and reduce the demand for the TNC's products and thus can negatively impact the flow of FDI. High loan interests translate into the cost burden of a company and have been evidenced by the companies that decide to halt operations and move to other regions with low interest rates. From the perspective of an investor, low interest rates are better as compared to high rates because returns are high when the interest charges are low. Reduction of interest on loans was introduced by the government of the Qatar for the purpose of creating an ideal location for international investments. Destinations with such incentives are bound to attract more investors as compared to destinations that charge high interest on loans.

Moreover, the presence of financial institutions with sufficient liquidity and transparency to grant quick loans at competitive rates is an important determinant. The investors, market participants, and analysts have generally been very comfortable with the Qatar banking sector comprising of 18 banks, including 11 domestic lenders and seven foreign players, catering to their ever-growing needs. Liquidity is the essential lubricant of the financial engine. From it, all else follows - cash for investment, growth funding, corporate borrowing, right down to mortgage and rent payments and supermarket bills. Halt liquidity, and you halt the economy. The Qatar Central Bank, the supportive regulator always appears to spot the early warning signs and act promptly to protect all-important liquidity in the Qatar financial infrastructure.

Qatar's banking sectors have become a major component of the country's economy over the past few decades. The top-five largest institutions in Qatar are all domestic banks, and together hold more than $75 \%$ of total sector assets (QNB, 2016). In the five years leading up to 2014, the banking sector as a whole grew at a compound annual rate of more than $15 \%$, the fastest in the GCC.

Table 19 gives the ranking for the top 10 banks in the GCC by the Gulf Business magazine which is one of the leading regional business magazines and is the preferred magazine for decision-makers, corporate leaders and high-ranking government executives in the region. 
Table 19. Top 10 banks in the GCC in 2016

\begin{tabular}{lcccc}
\hline Bank & Assets $(\$ 000)$ & Net Profit $(\$ 000)$ & Rank & Country \\
\hline Qatar National Bank & $147,968,995$ & $3,112,298$ & 1 & Qatar \\
National Commercial Bank & $119,824,114$ & $2,439,581$ & 2 & Saudi Arabia \\
National Bank of Abu Dhabi & $110,689,847$ & $1,424,399$ & 3 & UAE \\
Emirates NBD & $110,688,858$ & $1,939,496$ & 4 & UAE \\
Al Rajhi Banking Corporation & $84,165,239$ & $1,901,353$ & 5 & Saudi Arabia \\
National Bank of Kuwait & $77,751,595$ & 976,997 & 6 & Kuwait \\
Samba Financial Group & $62,731,381$ & $1,390,459$ & 7 & Saudi Arabia \\
Abu Dhabi Commercial Bank & $62,147,319$ & $1,341,429$ & 8 & UAE \\
First Gulf Bank & $61,937,482$ & $1,638,776$ & 9 & UAE \\
Riyad Bank & $59,550,900$ & $1,079,861$ & & Saudi Arabia \\
\hline
\end{tabular}

Source: http://gulfbusiness.com

Qatar National Bank (QNB), which was established by the State in 1964 and is still controlled by the government, with more than $40 \%$ of Qatari banking sector assets, is the leading financial institutions in the GCC by assets, deposits, and lending. Based on the Group's consistently strong financial performance and its expanding international presence, QNB is currently ranked as the most valuable bank brand in The Middle East and Africa by Brand Finance Magazine. QNB is ranked as 'One of the World's Strongest Banks' by Bloomberg Markets since 2013. The Global Finance Magazine ranked QNB as 'One of The Top 50 Safest Banks in the World' in 2013. For two years, 2014 and 2015, the Bank was recognized as 'The Best Bank in The Middle East' by Euromoney Magazine (QNB, 2016). Moreover, the current local factors look set to support continued growth, in particular, the government's current spending commitments, which include building infrastructure in preparation to host the 2022 FIFA World Cup. This bodes well for the banking sector, which has traditionally relied on government projects for growth.

\subsection{Availability of Land and Other Facilities at Subsidized Rates}

The cost of buildings and land is another factor that domestic companies and multinational corporations take into consideration while making investment decisions. Companies would prefer an investment destination that is less costly and does not take up much expenditure (Razin et al., 2007). Qatar offers plenty of investment incentives to attract investments into the country which includes providing electricity, water, and gas at lower rates, charging nominal lease rates on industrial land, import tax exemption on heavy duty machinery, their spare parts and on raw materials, and flexible regulations and procedures to import skilled and unskilled workforce. There are no restrictions on money exchange and transfer of profits abroad. Allocates the required plot of land to the foreign investor to establish his investment project for a long period of time extending to even 50 years, which is renewable. The various exemptions, incentives and privileges offered are published by the Ministry of Foreign Affairs and few of them are listed below:

- The foreign investor has the right to import for his investment project what is necessary for the establishment, operation or expansion.

- The invested foreign capital is exempted from tax income for no more than ten years from the day the project was operated.

- Customs exemptions on the project's imports of machinery and equipment necessary for its establishment.

- Customs exemption on industrial project on its imports of raw materials or half-manufactured goods necessary for production and not available in the local market.

- $\quad$ Provide the project with power, petroleum, water and natural gas at competitive prices.

- Flexible procedures to bring industrial workforce

- Health services at reasonable rates. (Ministry of Foreign Affairs, 2016)

All these exemptions, incentives, and privileges are added factors attracting FDI into Qatar and will help Qatar to emerge as the most favoured FDI destination in the GCC in the near future.

\subsection{Ease of Doing Business}

The World Bank Group's Doing Business report tracks the regulatory and bureaucratic systems of nations by conducting detailed annual surveys with the goal to provide an objective basis for understanding and improving 
the regulatory environment for business around the world. Doing Business report captures several important dimensions of the regulatory environment as it applies to local firms. It provides quantitative indicators on regulation for starting a business, dealing with construction permits, getting electricity, registering property, getting credit, protecting minority investors, paying taxes, trading across borders, enforcing contracts and resolving insolvency (Table 20). These reports provide data on the ease of doing business, rank each location, and recommend reforms to improve performance in each of the indicator areas.

Table 20. What doing business report measures

\begin{tabular}{ll}
\hline \multicolumn{1}{c}{ Parameters } & \multicolumn{1}{c}{ What Doing Business Measures } \\
\hline $\begin{array}{l}\text { Starting a business } \\
\text { Dealing with construction permits }\end{array}$ & $\begin{array}{l}\text { Procedures, time, cost and paid-in minimum capital to start a limited liability company } \\
\text { Procedures, time and cost to complete all formalities to build a warehouse and the quality control } \\
\text { and safety mechanisms in the construction permitting system }\end{array}$ \\
Petting electricity & $\begin{array}{l}\text { Procedures, time and cost to get connected to the electrical grid, the reliability of the electricity } \\
\text { supply and the cost of electricity consumption }\end{array}$ \\
Registering property & $\begin{array}{l}\text { Procedures, time and cost to transfer a property and the quality of the land administration system } \\
\text { Getting credit }\end{array}$ \\
Protecting minority investors & $\begin{array}{l}\text { Minority shareholders' rights in related-party transactions and in corporate governance } \\
\text { Paying taxes }\end{array}$ \\
Prading across borders & Time and cost to export the product of comparative advantage and import auto parts \\
Enforcing contracts & Time and cost to resolve a commercial dispute and the quality of judicial processes \\
Resolving insolvency & Time, cost, outcome and recovery rate for a commercial insolvency and the strength of the legal \\
& framework for insolvency
\end{tabular}

Source: Doing Business Report, World Bank Group.

Doing Business Report 2016 ranks economies based on their ease of doing business, from 1-189. A high ease of doing business ranking means the regulatory environment is more conducive to the starting and operation of a local firm. The rankings are determined by sorting the aggregate distance to frontier scores on 10 topics, each consisting of several indicators, giving equal weight to each topic. Table 21 gives the global ranking for the GCC and the parameter-wise detailed ranking is given in Table 22. The rankings for all economies are benchmarked to June 2015 .

Table 21. Ease of doing business: GCC economies in 2015

\begin{tabular}{lcc}
\hline Economies & Ease of Doing Business Global Rank* & Filtered Rank \\
\hline United Arab Emirates & 31 & 1 \\
Bahrain & 65 & 2 \\
Qatar & 68 & 3 \\
Oman & 70 & 4 \\
Saudi Arabia & 82 & 5 \\
Kuwait & 101 & 6 \\
\hline
\end{tabular}

Source: Doing Business Report 2016, World Bank Group.

*2015 rank out of 189 economies.

In the World Bank's 'Doing Business 2016' report, Qatar ranked 68th out of 189 countries for ease of doing business. Qatar is ranked third in the GCC following the UAE (31st) and Bahrain (65th). The report noted that Qatar had improved in the trading across borders category by reducing the time required for port handling and importing goods, ahead of the UAE, Kuwait, and Saudi Arabia. Globally, Qatar ranks first in the ease of paying taxes category, along with the UAE. This is due to reforms that have been made in the last five years, leading to the elimination of certain requirements associated with corporate income tax returns. Qatar also scored highly in the dealing with construction permits category, ranking eighth overall, ahead of Bahrain $\left(9^{\text {th }}\right)$, Saudi Arabia $\left(17^{\text {th }}\right)$, Oman $\left(46^{\text {th }}\right)$ and Kuwait $\left(133^{\text {rd }}\right)$. 
Table 22. Ease of doing business: Parameter-wise ranking of GCC economies in 2015

\begin{tabular}{|c|c|c|c|c|c|c|c|c|c|c|}
\hline Economies & $\begin{array}{l}\text { Starting a } \\
\text { Business }\end{array}$ & $\begin{array}{l}\text { Dealing with } \\
\text { Construction } \\
\text { Permits }\end{array}$ & $\begin{array}{l}\text { Getting } \\
\text { Electricity }\end{array}$ & $\begin{array}{l}\text { Registering } \\
\text { Property }\end{array}$ & $\begin{array}{l}\text { Getting } \\
\text { Credit }\end{array}$ & $\begin{array}{l}\text { Protecting } \\
\text { Minority } \\
\text { Investors }\end{array}$ & $\begin{array}{l}\text { Paying } \\
\text { Taxes }\end{array}$ & $\begin{array}{l}\text { Trading } \\
\text { Across } \\
\text { Borders }\end{array}$ & $\begin{array}{l}\text { Enforcing } \\
\text { Contracts }\end{array}$ & $\begin{array}{l}\text { Resolving } \\
\text { Insolvency }\end{array}$ \\
\hline UAE & 60 & 2 & 4 & 10 & 97 & 49 & 1 & 101 & 18 & 91 \\
\hline Bahrain & 140 & 9 & 77 & 25 & 109 & 111 & 8 & 85 & 101 & 85 \\
\hline Qatar & 109 & 8 & 111 & 28 & 133 & 122 & 1 & 119 & 112 & 51 \\
\hline Oman & 149 & 46 & 60 & 33 & 126 & 134 & 10 & 69 & 70 & 105 \\
\hline Saudi Arabia & 130 & 17 & 24 & 31 & 79 & 99 & 3 & 150 & 86 & 189 \\
\hline Kuwait & 148 & 133 & 128 & 68 & 109 & 66 & 11 & 149 & 58 & 122 \\
\hline
\end{tabular}

Source: Doing Business Report 2016, World Bank Group.

Doing Business data shows that in 2003, it took an average of 51 days worldwide to start a new business, whereas it can be done in 20 days now.

\section{Conclusion}

Over the years, Qatar has made tremendous progress and is emerging as the most attractive FDI destination in the GCC. The Global Competitiveness Report 2015-2016 ranks Qatar as the most competitive economy in the GCC and globally the $14^{\text {th }}$ best. In the previous report UAE was the best in the GCC and globally the $12^{\text {th }}$, but this year it has dropped 5 places to rank 17, whereas Qatar has improved from rank 16 to 14, which is highly appreciated by the WEF.

A number of global business indexes and global ranking agencies have recognized the advantages offered by Qatar and has duly ranked Qatar as the emerging attractive FDI destination in the GCC. The parameters making Qatar the emerging attractive destination in the GCC are potential for a growing market as it has the highest per capita income in the world, is one of the fastest-growing economies in the world, posting average annual GDP growth of $8.6 \%$, has a rapid population growth of more than $7.2 \%$ annual average since 2010 due to the influx of foreign workers and tourist arrivals increasing at an annual average rate of $11.5 \%$; an expanding infrastructure, an extremely safe environment with low political risk, negligible bribery and corruption, high productive and diversified labor force, competitive labor cost, well-developed financial market, low interest rates, technological readiness and innovation, friendly import-export policies, no restrictions on profit transfer or repatriation of capital, no income taxes, a flat $10 \%$ corporate income tax, very low import duties, availability of the best possible choices of accommodation, air travel connectivity provided by Qatar Airways, the World's Best Business Class Airlines with the Best Airline Staff in the Middle East ('www.worldairlineawards.com', 2016) and a currency, the Qatari Riyal, that is stable, secure and pegged to the US dollar. These factors, combined with a strategic geographic location and the ambitious leadership that leads the country with proper vision and long terms strategic plans, makes Qatar the fastest emerging attractive destination for Foreign Direct Investment in the GCC.

In addition, the hosting of the FIFA 2022 World Cup will also give the country greater respect as more people will visit it and realize how it is a key nexus of commerce, investment, and tourism. The ongoing projects and developments in preparation for this mega event are quite tremendous; at this rate of progress by 2022, Qatar will be one of the most vibrant and progressive countries in the world.

This study has its limitations as it is focused only on the factors favoring the flow FDI into a country. It would have been more holistic if factors hindering FDI was also included. There is plenty of scope for further studies in the future, which may be studied on factors hindering the flow of FDI into the GCC.

\section{References}

Almutawa, A. M., \& Maniruzzaman, A F. M. (2014). The UAE's Pilgrimage to International Arbitration Stardom: A Critical Appraisal of Dubai as a Centre of Dispute Resolution Aspiring to Be a Middle East Business Hub. Journal of World Investment and Trade, 15, 193-244. http://dx.doi.org/10.1163/22129000-01502006

Banga, R. (2003). Impact of government policies and investment agreements on FDI inflows to developing countries. Working paper No. 116, Indian Council for Research on International Economic Relations, New Delhi, pp. 1-47.

Brakman, S., \& Harry, G. (2008). Foreign Direct Investment and the Multinational Enterprise. Cambridge, MA: MIT Press. http://dx.doi.org/10.7551/mitpress/9780262026451.001.0001 
Campa, J. M. (1993). Entry by Foreign Firms in the U.S. Under Exchange Rate Uncertainty. Review of Economics and Statistics, 75(4), 614-22. http://dx.doi.org/10.2307/2110014

Carr, D. L., Markusen, J. R., \& Maskus, K. E. (2001). Estimating the Knowledge-Capital Model of the Multinational Enterprise. American Economic Review. http://dx.doi.org/10.1257/aer.91.3.693

Casi, L., \& Resmini, L. (2010). Evidence on the determinants of foreign direct investment: The case of EU regions. Eastern Journal of European Studies, 1(2), 93-118.

Caves, R. E. (1971). International Corporations: The Industrial Economics of Foreign Investment. Economica, 35(141), 1-27. http://dx.doi.org/10.2307/2551748

Chandalert, A. (2000). The Determinants of U.S. Direct Investment in Thailand: A Survey on Managerial Perspectives. Multinational Business Review, 8(2), 82-88.

Cho, J. W. (2003). Foreign direct investment: determinants, trends in flows and promotion policies. Investment promotion and enterprise development bulletin for Asia and Pacific, Economic and Social Commission for Asia and Pacific, Thailand, pp. 99-102.

Chopra C. (2003). Foreign investment in India (1st ed., pp. 34-45). New Delh: Deep and Deep Publication.

Doing Business Global Ranking 2016. World Bank Group. Retrieved from http://www.doingbusiness.org/rankings

Dunning, J. H. (1973). The determinants of international production (pp. 289-336). Oxford Economic Papers.

Erdal, F., \& Tatoglu, E. (2002). Locational determinants of foreign direct investment in an emerging market economy: Evidence from Turkey. Multinational Business Review, 10(1).

Gedam, R. (1996). Determinants of FDI and India's experience (2nd ed., pp. 82-100). New Delhi: Deep and Deep Publication.

Global Competitiveness Report. World Economic Forum. Retrieved from www.weforum.org/gcr

Global Financial Centers Index (2016). Retrieved from http://www.longfinance.net/global-financial-centre-index-19/992-gfci-19.html

Gulf Business. Retrieved from http://gulfbusiness.com/lists/top-50-gcc-banks-2016/\#.V9EpdSh97IU

Index of Economic Freedom. (2016). Retrieved from http://www.heritage.org/index/pdf/2016/pressreleases/THF-2016-middle-east-north africa.pdf

Khachoo, A. Q., \& Khan, M. I. (2012). Determinants of FDI inflows to developing countries: A panel data analysis. Centre for Development Studies, Trivandrum, Kerala. Retrieved from https://mpra.ub.uni-muenchen.de/37278/1/MPRA_paper_37278.pdf

Kravis, I., \& Lipesey, R. (1982). The location of overseas production and production for export by US Multinational firms. Journal of International Economics, 12(3), 201-23. http://dx.doi.org/10.1016/0022-1996(82)90036-8

Logistics Performance Index. (2016). Retrieved from http://pi.worldbank.org/international/global

Makki, S. S., Somwaru, A., \& Bolling, C. (2004). Determinants of Foreign Direct Investment in the foodprocessing industry: A comparative Analysis of Developed and Developing Economies. Journal of Food Distribution Research, 35(3), 60-7.

Mauro, P. (1995). Corruption and Growth. Quarterly Journal of Economics, 110, 681-712. http://dx.doi.org/10.2307/2946696

Melo, L., \& Quinn, M. A. (2015). Oil, Foreign Direct Investment and Corruption. The International Journal of Business and Finance Research, 9(1), 33.

Milner, H. V. (2013). Introduction: The Global Economy, FDI, and the Regime for Investment. World Politics, 66(1), 1-11. http://dx.doi.org/10.1017/S0043887113000300

Mina, W. (2007). The Location Determinants of FDI in the GCC Countries. Journal of Multinational Financial Management, 17(4), 336-348. http://dx.doi.org/10.1016/j.mulfin.2007.02.002

Ministry of Foreign Affairs. (2016). Retrieved http://www.mofa.gov.qa/en/Qatar/Pages/InvestmentIncentives.aspx

Muysken, J., \& Samia, N. (2006). Deficiencies in Education and Poor Prospects for Economic Growth in the 
Gulf Countries: The Case of the UAE. The Journal of Development Studies, 42(6), 957-980. http://dx.doi.org/10.1080/00220380600774756

Na, L., \& Lightfoot, W. S. (2006). Determinants of foreign direct investment at the regional level in China. Journal of Technology Management in China, 1(3), 262-78. http://dx.doi.org/10.1108/17468770610704930

Neumayer, E., \& Indra, S. (2005). Trade Openness, Foreign Direct Investment and Child Labor. World Development, 33(1), 43-63. http://dx.doi.org/10.1016/j.worlddev.2004.06.014

OECD. (2000). Main determinants of FDI and its impact of foreign direct investment on China's economy. Working papers on international investment no. 4, prepared for OECD cooperation programme.

Overseas Development Institute. (ODI, 1997). Foreign direct investment flows to low income countries: A review of the evidence. Briefing paper no.3.

Oxford Business Group Country Report: Qatar. (2016). Retrieved from http://www.oxfordbusinessgroup.com/qatar-2016/economy-0

Qatar Corruption Report. Retrieved from http://www.business-anti-corruption.com/country-profiles/qatar

QNB. (2016). Retrieved from http://www.qnb.com/cs/Satellite/QNBQatar/en_QA/enAboutQNB

Raphael, E., Fayad, G., \& Prasad, A. (2013). The Importance of the GCC for the Wider Region. http://dx.doi.org/10.1093/acprof:oso/9780199683796.003.0009

Rauf, S., Mehmood, R., Rauf, A., \& Mehmood, S. (2016). Integrated Model to Measure the Impact of Terrorism and Political Stability on FDI Inflows: Empirical Study of Pakistan. International Journal of Economics and Finance, 8(4). http://dx.doi.org/10.5539/ijef.v8n4p1

Razin, A., \& Efraim, S. (2007). Foreign Direct Investment: Analysis of Aggregate Flows. Princeton, N.J: Princeton University Press.

Resmini, L. (2000). The Determinants of Foreign Direct Investment in the CEECs. Economics of Transition, 8(3), 665-89. http://dx.doi.org/10.1111/1468-0351.00060

Root, F., \& Ahmed. (1979). Empirical Determinants of Manufacturing Direct Foreign Investment in Developing Countries. Economic Development and Cultural Change, 27(4), 751-767. http://dx.doi.org/10.1086/451139

Schneider, F., \& Bruno, S. F. (1985). Economic and Political Determinants of Foreign Direct Investment. World Development, 13(2), 161-175. http://dx.doi.org/10.1016/0305-750X(85)90002-6

Singh, H., \& Jun, K. W. (1995). Some new evidence on determinants of foreign direct investment in developing countries. Policy research working paper no. 1531 - in ODI.

Smarzynska, B. K., \& Wei, S. J. (2001). Corruption and composition of foreign direct investment: Firm-level evidence. World Bank Working Paper.

Tanzi, V., \& Davoodi, H. (1997). Corruption, public investment and growth. IMF Working Paper, WP/97/139.

Transparency International, the Corruption Perceptions Index (CPI). Retrieved from http://www.transparency.org/cpi2015

Uwubanmwen, A. E., \& Ajao, M. G. (2012). The Determinants of foreign direct investment in Nigeria. International Journal of Business and Management, 7(24), 67-77.

World's Top $\quad 100 \quad$ Airlines in 2016. Retrieved from http://www.worldairlineawards.com/awards/world_airline_rating.html

Zhao, H., \& Zhu, G. (2000). Location factors and country-of-origin differences: An empirical analysis of FDI in China. Multinational Business Review, 8(1), 60-73.

\section{Copyrights}

Copyright for this article is retained by the author(s), with first publication rights granted to the journal.

This is an open-access article distributed under the terms and conditions of the Creative Commons Attribution license (http://creativecommons.org/licenses/by/4.0/). 